${ }^{201} \mathrm{~T}$ 運動負荷心筋シンチグラフィーの評価法として, プラナイメージから wash out rateを表現するイメージ を作成するために基礎的唡討を行った。

デー夕集収方法と処理方法を数通り行い, wash out の 式 (Initial-Delayed)/Initial

Delayed/Initial

に基いたイメージを作成した。

その結果プリセットタイム法と Goris 氏法の組み合わ せが wash out rate image の作成に有利であり，ROI 解 析・circumferential profile・CAGとも良く相関した image が得られ，他の data との併用により，有用性があ るものと思われる。

\section{RI による門脈イメージング}

山梨県核医学技術研究会 新井誉夫

門脈王方進症における側副血行路の診断は，患者の予 後，治療方針の決定に不可欠である。今回われわれは， 経皮的に脾実質内へ RI を注入することにより門脈血流 動態を視覚的にとらえることができた，得られたイメー ジは，正常を含め 4 つの型に分けられた。側副血行路を 認めず門脈走行にだ行を示したもの，また上行および下 行に向う側副血行路を認めたもので上行性は食道静脈瘤 また下行性は下腸間膜静脈への逆流と思われた。撮像時 間は門脈が出現している時間が 3 秒程度であるため, 0.5 秒から1.0秒間隔で10秒から20秒間撮像を行えば充分で ある。

\section{6. 県内におけるキュリーメータの実態調查}

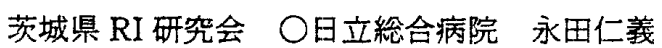
土浦協同病院 平井正幸 水戸済生会病院 菊地真平

下館市民病院 䋊川力

東京医大霞ヶ浦病院 宮内兼義 筑波大学付属病院 畠山六郎

国立水戸病院 高橋利春

線源測定用に各種の測定器が用いられているが, 県内 のRI 施設の使用機種とその利用状況を調查および測定 器の感度特性, 線量率特性を実測し, 適正な利用とRI 投 与量の測定精度の向上を目的とする。

結果は性能試験を行っている施設は50\%鸡であった。 感度試験上は標準值士10\%誤差内 $82 \%$ であった。測定器 の well の型により等線量曲線に大きな差が生じた. well の型は奥行きが樑く入口の巾が狭い方がよく，アルゴン 封入電離箱型に良い結果が得られた。感度差がある機種 にても注射器の最大目盛の 6〜 7割以下の液量にて使用 すれば問題ない，測定結果は各施設に感度比, 補正係数
を記入して報告した。

\section{座長策約}

今回の核医学娭查技術についての発表は 5 題であった。 第30回関東・東京部会記念誌編集委員会の研究発表の推 移によると, 核医学関係の S. 54〜 58年の発表題数は34件 であり，毎年平均 6〜 7 題となっている.S. 59年からの 5 年間はどのように推移するか，核医学の衰勢はどうか, 興味深いところである。

演題12の横山氏(千葉県がんセンター) は，肝疾患(腫 瘍）における in vivo 検查と in viro 検查の有用性につい て比較検討した，症例の大半が転移性肝癌であるため， AFP の陽性率が低值であるのは当然といえる。また SOLの大きさと CEA の陽性率とに相関が認められると したが，症例数も少なく，原発巣の状態，他部位への転 移の有無等さらに検討を重るてもらいたい。また SPECT を併用した肝シンチグラムと，CT，US を比較 し，3者に優劣はないとしているが，他の学会等の評価 ではいかがであろうか．肝疾患における各検查の長所を 生かした dicission tree の確立と経過観察での各検査の 有用性など多岥にわたる検討を今後期待したい。

演題13の黒川氏（埼玉県立小児医療センター）は，小 児の大腿骨の骨幹部と骨端部の RI の集積を軟部組織と の比で求め, 定量的解析を行い, 線維性骨炎, 骨脱灰お よび骨粗鬆症の判定と経過観察に有用であるとした。演 者も求べたように，骨代謝の著しい年令群であるため， 個々の症例により，骨へのRI医薬品の集積率には大き な幅があり，正常值の把挃が大変難しい，年令別正常值 の確立等研究を進めてもらいたい.

演題140平瀬氏 (杏林大学病院)は, ${ }^{201} \mathrm{Tl}$ 運動負荷シ ンチグラムから wash out rateを表わす functional image を作成する data収集方法，処理方法を発表した。 その結果, preset time 法とGoris氏法によるbackground 処理の組合せが最良であるとした，data 処理に よる定量的解析には original data 量と前処理方法が大 きな要因となる，演者は $128 \times 128$ Matrix， $300 \mathrm{sec}$ 収集 により,最大 data 量が 1 Matrix 当たり 800 count で, 前 処理として 9 点 smoothing を 4 回施行を一定にしてい ると述べた。 data 処理は各メーカとも独自のソフトプロ グラムにより行われ，解析 dataに互換性のないのが現 状である. 早急に前処理方法も含めて, data 処理の標準 化が必要である。奥野氏（日大板橋病院）より運動負荷 後の $\mathrm{Tl}$ 再分布の影響があるため，撮像時間を20分以内 また撮像部位の制限等のコメントがあった。

演題15の新井氏（山梨医大）は，超音波装置で位置確 